\title{
CIVIC AND CULTURAL IDENTITIES AND THE ENLIGHTENED LITHUANIAN NOBILITY (BASED ON THE EGO-DOCUMENTS OF THE OGIŃSKI AND PLATER FAMILIES)
}

\section{KEYWORDS}

civic identity; cultural identity; the Enlightenment; the Plater family; the Ogiński family; ego-documents; correspondence collections

\section{Introduction. The Concept of Identity}

There are several ways of approaching civic and cultural identities. In traditional sociological research identity is defined as a collective phenomenon founded upon common tradition and common history, shared values and norms, confessional affiliations, ethnic belonging, language, roles played in society, as well as ability to appropriate signs and symbols of culture. These identity-defining characteristics

Ramunė Šmigelskytè-Stukienè - dr, Lithuanian Institute of History / National Museum - Palace of Grand Dukes of Lithuania, Kražių 5, Vilnius 01108, Lithuania; e-mail: smigelskyte.stukiene@ gmail.com 
either link or separate different societal groups from each other. In this way identity defines one's belonging to a given group. It determines the presence and functioning of an individual in a concrete sociocultural space (Koç 2006; Giddens 1991).

However, neither social nor cultural identity is a constant phenomenon. Just like culture, identity is a complex and always changing structure that creates ever new communal connections: taking some elements from the past, while rejecting other, as well as borrowing some elements from different contexts. An established identity can create an illusion of stability, but in fact in time it may change, multiply, eventually transform and even vanish together with its markers. As Stuart Hall notes, cultural identity is formed at the crossroads of cultural discourses and practices, which makes the individual a representative of a certain discourse (Hall $1990 ; 1994)$. Cultural identity can also be understood as a construct formed by institutions and instilled through certain educational and discursive practices. In this respect, what remains of utmost importance is not only the origin or social affiliation of the individual, but also the process of their upbringing and cultural education, which helps preserve the essential structures of cultural identity and pass them on to the future generations.

According to sociologist Manuel Castells, a social group or an individual (social actor) constructs identity as based on a set of certain cultural attributes. Therefore, the same group (collective actor) or individual may have many identities. Identities exist only when social actors internalize them and construct their meaning around this internalization. Identity is not something that is given automatically as part of social life. From a sociological perspective, all identities are constructed. According to Castells,

The construction of identities uses building materials from history, from geography, from biology, from productive and reproductive institutions, from collective memory and from personal fantasies, from power apparatuses and religious revelations. But individuals, social groups, and societies process all these materials, and rearrange their meaning, according to social determinations and cultural projects that are rooted in their social structure, and in their space/time framework (Castells 2010: 7).

Castells distinguishes identity from the roles which a group or an individual plays in society, and which depend on the arrangements between individuals and social institutions. The proposal put forward by Castells is an acceptable and convenient tool that helps analyse the self-perception of Polish and Lithuanian nobility and to define the civic and cultural identities of this part of society (Bairašauskaitè 2011: 54).

On the other hand, even if we reject the analysis of social roles, we will not be able to identify the civic and cultural identity of an individual or a group in 
isolation from the political and cultural context. Therefore, a research of civic and cultural identities in the Grand Duchy of Lithuania in the second half of the eighteenth century is tightly linked with both the Lithuanian historical tradition, and the cultural and political context of the Enlightenment, as Kristina Mačiulyté (Mačiulyte 2005; 2006) has observed.

The political, social, economic and cultural changes of the second half of the eighteenth century (i.e. economic modernization, the development of capitalism, the spread of the ideas of libertinism, the rising question of abolition of serfdom, the establishment of the Enlightenment ideology) and, in particular, the political transformations of the final decades of the century - the first (1772) and the second (1793) partitions of the Polish-Lithuanian Commonwealth and the final liquidation of the state in 1795 - served as the socioeconomic, political and cultural factors that shaped the nobility's identity in the Age of Enlightenment and the way it was expressed. After the third partition of the Polish-Lithuanian Commonwealth, the issue of civic identity became rather complicated for all social classes, regardless of their influence in society. After the loss of the state, the identity imposed from the outside was accepted (Beresnevičiūtè-Nosálová 2001: 49-58; Mačiulytè 2006: 102-118).

A rich base of textual sources provides excellent opportunities to identify the political and social views and religious beliefs of the Lithuanian nobility as well as the cultural field of their activities and creative work. The correspondence collections of the aristocrats of the Grand Duchy of Lithuania provide important information for the research of the political activity and sociocultural practices of the ruling elite of the Polish-Lithuanian Commonwealth. These under-researched collections allow for deeper understanding of the communication channels of the eighteenth-century Polish and Lithuanian society and contacts of its elite with the political and cultural centres of both the East and the West. They also shed light on the civic and cultural identity of the representatives of the elite and the changes thereof in the face of the destruction of the state. The partitions of the Commonwealth in 1773, 1793 and 1795, during which most of the territory of the Grand Duchy of Lithuania was incorporated into the Russian Empire, forced local aristocrats to choose between active struggle, emigration, or collaboration with the occupying power. Testimonies of these choices can be found in memoirs, diaries, and personal and official letters kept in family archives, which not only reveal motives for different choices but also show which cultural space - Eastern or Western - was the beacon of hope for the future.

The aim of this article is to examine the civic and cultural identities of two aristocrats who held important offices among the ruling elite of Lithuania and left significant cultural legacy: the last Vice-Chancellor of Lithuania, publicist and 
economist duke Kazimierz Konstanty Plater (1749-1807), and the last Grand Treasurer of Lithuania, Senator of the Russian Empire, diplomat and composer duke Michał Kleofas Ogiński (1765-1833).

\section{Researching Identities on the Basis of Ego-Documents of the Plater and the Ogiński Families}

Due to the complicated historical twists, both the personal archive of Michat Kleofas Ogiński and the ego-documents of Kazimierz Konstanty Plater are split into several collections of documents that are currently held in the archives of different countries (Lithuania, Poland, Russia, Ukraine, and Belarus). The Lithuanian State Historical Archives, The Ogiński Family Collection, fond no. 1177, and the Manuscript collection of Vilnius University library have only a small part of the personal Ogiński archive. The main documents from the Ogiński archive were moved to Russia still in the nineteenth century and are currently deposited in the Russian State Archive of Ancient Acts in Moscow. Ogiński's political and diplomatic correspondence from the period between 1790 and 1792 is housed in the Central Archives of Historical Records in Warsaw. It is important to note that in order to the research Ogiński's civic and cultural identity, it is crucial to examine not only his correspondence with politicians and diplomats from Western Europe or Polish and Lithuanian nobility, but also his diary (Ogiński 1778), his Mémoires (Mémoires; Ogiński 1826-1827 I-IV), political speeches (Ogiński 1786; 1793a, 1793b; 1793c, etc.), projects submitted to Emperor Alexander I in 1810-1811 (Ogiński 1827 III: 47-70, 77-80, 92-110), and essays in the form of letters. His Lettres sur musique (Letters about Music [Ogiński 1956; Ogińskis 2014]), a text that describes Western European musical culture, and Lettres sur les éducation des enfants (Letters about Education; LVIA F1177/1 87, 5820, 5821) show the main trends in children's education at the time and the civic ideals that were instilled in them (Ogińskis 2019).

The epistolary heritage of Kazimierz Konstanty Plater, deposited in the Lithuanian State History Archives (The Plater Family Collection, fond no.1276), is slightly smaller in volume. Plater's annual notes and diary are kept in the Wróblewski Library of the Lithuanian Academy of Sciences. The ego-documents, supplemented with Plater's letters to King Stanisław August Poniatowski, are deposited in the Prince Czartoryski Library in Kraków.

Plater's political views and civic identity are also conspicuous in the treatises and projects published in the last decades of the eighteenth century (Plater 1789a; $1789 \mathrm{~b} ; 1790 ; 1791)$. Among his essays, written in the form of letters, one of the most important ones was published in 1788. It is a nine-piece political text Listy 
posta do ojca na wsi mieszkajacego (Letters of an Envoy to His Father who Lives in the Countryside) which suggests a way for Poland and Lithuania to draw closer to Russia (Plater 1788a).

\section{Two Biographical Sketches: Plater and Ogiński}

Kazimierz Konstanty Plater was the son of the fourth ranking Lithuanian nobleman, the castellan of Trakai Konstanty Ludwik Ogiński and Augusta Ogińska. He was the middle of three brothers (Zielińska 1981b: 673-675). Kazimierz Konstanty spent his childhood in Latgala (now Latvia) in the Kraslava manor of his parents, where he was home schooled. There is no reliable data on Plater's teachers or the details of his home education. However, the superior erudition of his father, his close links with the duke of Courland Charles (Tyszkiewicz 1870: 13), and his active participation in resolving the issues between the PolishLithuanian Commonwealth and the Duchy of Courland, and Semigallia suggest that the standards of the education that was supposed to prepare the Ogiński brothers for career in politics were high.

The ample written legacy that Kazimierz Konstanty Plater left behind shows that he accepted and reflected upon the ideas of the Enlightenment. He was well familiar with the most up-to-date economic and fiscal ideas, and was interested in credit policies and economic development (Plater 1789b; 1791). His rich personal library, accumulated over the entire life, reflects his socio-political and cultural interests (Konarski 1967: 110-112; Rączka 2013: 61-67).

As one can judge from the surviving book catalogue of the library that the Plater family had at their manor house in Daugeliškis, alphabetically compiled in the early 1880s, the library housed 350 volumes of educational books necessary for the daily life at the manor and the home schooling of the children (LMAVB RS, F9-63/II). Among the encyclopaedic texts one may find comprehensive historical and geographic books as well as various dictionaries and manuals, as well as grammar books which could be used by the children and teachers alike. Naturally, the Platers had another large library in their palace in Warsaw.

Kazimierz Konstanty Plater started his political career at the age of twenty, which was a common practice in the Polish-Lithuanian Commonwealth. $\mathrm{He}$ earned the status of the elder of Livonia (1770) and the castellan of Trakai (1790). In the last years of the Commonwealth, he became the vice-chancellor (1793) of the Grand Duchy of Lithuania. He was a politician of pro-Russian persuasion, and a supporter of King Stanisław August (Zielińska 1981a: 665-672; Rolnik 2009a: 69-90). Plater was also a political writer, historian, bibliophile, physiocrat and a citizen of the world. In his treatise Kosmopolita do narodu polskiego 
(A Cosmopolite's Address to the Polish Nation; Plater 1790), he promoted the idea of cooperation between states and nations, and publicly demanded that serfdom should be abolished. Plater was a monarchist. However, he saw the future of the Polish and Lithuanian Commonwealth in close union with Russia. In his Ziawienie o przysztym losie Polski (A Vision of the Future Destiny of Poland; Plater 1788b), he argued that the crown of the Commonwealth should be hereditary and thus should be given to the grandson of Catherine II, Grand Duke Constantine, who could be adopted by Stanisław August. In this way, as Plater argued, the Commonwealth would be able to regain some territories that had been lost to Russia and Austria during the first partition and in the future could claim rights to some conquered lands in Turkey (Plater 1788b).

The idea of Grand Duke Constantine becoming a successor to the throne was nothing new. It was developed by Grigory Potemkin, a favourite of Russian Empress Catherine II, and his associates, and was made public on the eve of the meeting between Stanisław August and Catherine II in Kaniv in the spring of 1787. This idea found support among aristocrats of the pro-Russian faction, who hoped to implement, with the help from Russia, a federal model of governance in the PolishLithuanian Commonwealth, as well as among some of the supporters of Stanisław August. The pro-Russian politicians considered the candidacy of Grand Duke Constantine to the throne of the Commonwealth as an alternative to the Wettin dynasty, supported by the patriotic-reformist faction (Zielińska 1991: 42-44).

As a monarchist, Plater was deeply convinced that the state simply "could not exist without a king" and that a hereditary throne was more beneficial than free elections, which "had long ago become only a fiction to cover up foreign interference" (Plater 1790: 24; Grześkowiak-Krwawicz 2000: 238). He was probably the first one to widely circulate the argument about the negative effect that the rule of the magnates has on nation, noting that this very "fight of the magnates against the throne (i.e. the King) is devastating to the nation", and that this part of society gains most from the election of the King (Plater 1790: 25-28). Considering whether a successor of Stanisław August must be a fellow countryman or a foreign ruler, Plater argued that the Commonwealth is not yet ready for the election of a king from a local dynasty, and that proposing any local candidates would stir unrest and internal struggle for power. Plater suggested the election of a foreigner, which would be most beneficial for the Commonwealth because of his political ties and position. Plater thus desired to see the grandson of the Russian Empress on the Polish and Lithuanian throne. His opinion reflected the objectives of the pro-Russian faction (Rolnik 2009b: 390).

Only a year after formally supporting the establishment of constitutional monarchy and the introduction of the Constitution of 3 May 1791, Plater was 
among those that argued for the abolishment of the Constitution and at the end of 1792, as a delegate of Lithuanian nobility, he travelled to Petersburg to express gratitude to Catherine II for the re-establishment of the old order (Plater 1856). Plater remained humble and submissive to the Russian rule until the end of his life (Plater 1856: 682-686; Rolnik 2009a: 86-88; 2009b: 204, 337; Zielińska 1981a).

Michał Kleofas Ogiński, the only son of the third ranking Lithuanian nobleman, Andrzej Ogiński, the voivode of Trakai, and the Polish noblewoman Paulina Szembek, adopted a different political view. He received his education, closely based on the ideas of the Enlightenment, from his personal tutor, Frenchman Jean Rolay. Ogiński started his political career as a representative of the nobility of the Trakai voivodeship at the Warsaw Sejm of 1786 (Ogiński 1786; Šmigelskytè-Stukienè 2015a: 31-34). Later he was actively involved in promoting the economic development of the country and submitted motions to the Sejm on the improvement of state administration. In the period from 1788 to 1790 , he was part of the Treasury Commission of Lithuania and brought forward projects on the reorganization of the network of customs offices, trade improvement, and the foundation of Šventoji Port. From 1790 to 1791, he was a royal envoy to the Commonwealth to the Netherlands (Šmigelskytė-Stukiené 2015a: 99-129). He sought closer political and economic ties with Great Britain and to that end he left for a mission in London (Libiszowska 1974: 177-193). He maintained links with the Royal Court of Berlin. Ogiński actively supported the idea of granting political rights to the Third Estate (Šmigelskytè-Stukienè 2015b: 104-122). He also supported the Constitution of 3 May 1791 and gave a solemn oath to abide by it, despite having doubts if Stanisław August could, as a king, defend the country against the threat from Russia. In a letter to a Portuguese diplomat António de Araújo e Azevedo, he wrote:

It is important that the King, who has just received his titles due to the love and gratitude of the nation, should become the nation's leader... Well, my pen is falling from my hand when I think that this King, good but weak, well-wishing but lacking in courage and determination, to clearly express his will and make a resolute decision, would be the first one to look for ways to make peace, were Russia to pose the first of its threats. He will not forsake peaceful intentions or sacrifice peaceful life for a doubtful success in war and, possibly, forgetting his promises and the best of intentions, he will sacrifice the glory of Poland! Can I be wrong?! I hope for this more than I expect for it to actually happen, etc. (Michel Ogiński, Warsaw, 20 May 1791, Mémoires 1826-1827, I: 156-160).

After becoming the Grand Treasurer of Lithuania in 1793, Ogiński wanted to preserve the political existence of the nation after the partition. However, unlike Vice-Chancellor Plater, who sided with Russia, Ogiński was actively involved in 
the rebellions against the occupation in 1794 . He was not only a leader of the uprising in the Grand Duchy of Lithuania, but he also personally led two war-time missions of the rebels (Brusokas 2010: 153-168). After the defeat of the uprising, he moved to Western Europe and was active among the emigrant community. He tried to find support for the restoration of Poland and Lithuania in the Ottoman Empire, and wrote letters to Napoleon Buonaparte, hoping to get help for the Polish-Lithuanian Commonwealth (Dundulis 1972: 57-73).

Michał Kleofas Ogiński returned to Lithuania at the beginning of the nineteenth century and again put every effort to restore the statehood of Lithuania. In 1811, he wrote a memorandum on the restoration of the Grand Duchy of Lithuania and submitted it to the Russian Emperor Alexander I. At the beginning of 1812 he designed a project of the Constitution of the Grand Duchy of Lithuania, giving a legal status to the sovereign Lithuania (Sirutavičius 1991: 7-28; Dundulis 1972: 57-73). Having failed to implement these two ideas, Ogiński removed himself from political life and in 1822 he emigrated to Italy.

In historiography, political activities of both Ogiński and Plater in the period from 1792 to 1793 are viewed in a negative light because of the involvement of these two noblemen in the Targowica confederation which abolished the Constitution of May 3, and also because of their participation in legalizing the second partition of the Polish-Lithuanian Commonwealth. As Dariusz Rolnik, a Polish historian who examined Plater's political stance, argues, his choice may have been determined by his origins, i.e. the fact that he was not Polish. However, can the origins truly be the key element that determined the civic and cultural identity of the nobleman? What was it that motivated the two different choices made by the representatives of the Lithuanian political elite at the time? To answer this question, let us examine materials from the archives of the Platers and the Ogińskis.

\section{The Problem of the National Identity and Origin}

It is important to note that the archival heritage of both families is multilingual. French is the dominant language in the correspondence and works of Ogiński, some other texts are written in Italian and German. The Polish language was used in the public life of the Commonwealth and in correspondence with clients from Lithuania on landownership matters. Plater's letters, on the other hand, are mainly in Polish; only a fraction of the correspondence is written in German, Russian and Italian. He wrote his diaries, notes (LMAVB RS F9 68-71, F9 222, F9 137) and political essays (Plater 1788a; 1788b; 1789a; 1789b; 1791) in Polish. This shows that people in Plater's circle of correspondence were mainly limited to the 
nobility of the Grand Duchy of Lithuania. Letters exchanged with Livonian nobles were written in German, and those exchanged with military and administrative representatives of the Russian imperial government - in French and Russian.

An analysis of the linguistic spectrum of the letters helps examine the problem of the national identity and origin in more detail. One should bear in mind that both the Ogińskis and the Platers did not have local (Lithuanian or Polish) roots. Ogiński was a descendant of Old Ruthenian dukes who moved to Lithuania in the sixteenth century and in a couple of decades ascended to economic and political power (Vilimas 2010). Plater came from the Plater family of Livonian Germans who had their roots in the twelfth-century Westphalia (Konarski 1967). However, in the eighteenth century both the Ogińskis and the Platers considered themselves Poles of Lithuanian origin (Gente lituanus natione polonus), and their family members mainly corresponded in French.

The preserved letters by Plater and Ogiński to their children show that in both families children's education was based on the ideological premises of the Enlightenment and included practical knowledge of key Western European languages (French, German, English, Italian), and studying multilingual literature and the foundations of the Enlightenment philosophy (Šmigelskytė-Stukienè 2018b: 130-134). However, their educational strategies were different. Ogiński invested his highest hopes in the youngest son, who was tutored by the Swiss educator Jean Ruegger, which shows that Ogiński was hoping that his son would one day be studying at the University of Geneva (Šmigelskytė-Stukienè 2018a: 158-161). By contrast, Plater sent all of his four sons to a private school in Warsaw and later supported them financially when they studied at the Vilnius University (Zielińska 1981a: 671; Manteufflowa 1981: 679; Šmigelskytė-Stukienè 2018b: 130-131).

My research has shown that in Kazimierz Konstanty Plater's family, French was gradually replaced by the Polish language. Such a conclusion can be drawn on the basis of Plater's wife, Isabella's letters to her husband. As a descendant of the Livonian German family of the Borch, Isabella Borch Plater undoubtedly spoke perfect German. In the early years of their marriage, she wrote to her husband exclusively in French (LVIA F1276/2 179). Later, however, her letters featured more and more Polish phrases and expressions, especially after a long period spent at the family residence in Daugeliškis (LVIA F1276/2 210: 94-96). In the last decades of the eighteenth century, Isabella wrote entire paragraphs in Polish (LVIA F1276/2 208: 12-13, 15, 39).

However, the use of Polish in private or public life in the Grand Duchy of Lithuania in the eighteenth century did not mean that in the political life one had adopted the Polish identity as well. In the federal set-up of the Commonwealth, the two parts of the state - the Polish Kingdom and the Grand Duchy of Lithuania 
- had separate governmental institutions, legal systems, offices and representatives in the Sejm. Therefore, both the last Grand Treasurer Ogiński and the last ViceChancellor Plater were firstly Lithuanian ministers, and their influence on political processes in the country depended on the number of supporters. As a long-standing politician, Plater, who had been present in the political life of the Grand Duchy of Lithuania since 1770s, undoubtedly had more supporters than Ogiński. The circle of Plater's clients can be identified based on the intensity and the volume of his surviving correspondence (LVIA F1276/2: 192-212). By contrast, as a politician of the younger generation, Ogiński, who started his political career as late as in the 1790s and spent two years in the diplomatic service in The Hague, could not attract numerous supporters from the local nobility. Nevertheless, Ogiński's active engagement in the 1794 uprising attracted a number of people not only from among the nobility, but also the townspeople (Šmigelskytè-Stukiene 2015b: 104-132).

\section{The Development of a New Identity after Losing the State}

Kristina Mačiulytė and Halina Beresnevičiūtè-Nosálová have already pointed out that in 1795 the nobility had already reconciled themselves to the loss of their homeland. Having preserved some rights and privileges and remaining loyal to the king, they forged a new identity (Mačiulytè 2006: 115; Beresnevičiūtè-Nosálová 2001: 49-55). At the end of the eighteenth and in the early nineteenth century efforts were made not only to preserve what was considered part of the old identity of a Polish and Lithuanian Commonwealth citizen, but also to adapt to the new situation. These processes were very rapid: after the 'death' of the motherland, the experience of becoming 'orphaned' was compensated by the oath of allegiance to the new sovereign who was given the name of the 'father of the homeland'. From a historical perspective, the way in which a person felt and understood their identity often seemed contradictory and is thus difficult to assess. However, the rhetorical clichés transferred to the new context serve as evidence of not only the inadequacy of their content, but also efforts to mitigate rising tensions (Mačiulytė 2006: 116-117).

It should be noted, however, that process of the reconciliation with the loss of homeland and the adjustment to the conditions of the occupation was different for each individual. According to Dariusz Rolnik, already during the first partition of the Republic (1772), Plater's activities suggest that he felt no regret about the loss of the territories of Poland and Lithuania. He adapted very easily to the new reality and sought to maintain a strong position in his 'little homeland'. It is presumed that this stance was the norm in the Plater family, and this 'norm' was inspired by a certain distanced attitude to the country where Plater pursued his political career 
which was shaped by his living near the border (Rolnik 2009a: 69-90). In 1795, Plater did not have to create a new civic identity. His obviously identified with the Russian imperial government.

Ogiński understood the situation differently. He returned to his homeland only six years after the fall of the Polish-Lithuanian Commonwealth. It took him another decade to become involved in the public life of the Russian Empire. As Beresnevičiūtè-Nosálová notes, in his Mémoires, he presents his decision to become a "minor courtier at the St. Petersburg Court" in 1810 as a sacrifice for the sake of his homeland. And this was not an attempt to make excuses, for in Mémoires he confesses to "terrible disgust", and at the same time fear that "his fellow citizens will not understand it" (Beresnevičiūtè-Nosálová 2001: 45). Still, the move was motivated by a higher purpose: "to convince the Emperor that he owes his new, loyal subjects a duty to return their lost Homeland and to cancel all the novelties introduced by the Russian authorities" (Ogiński 1827: 63). Ogiński saw such aspiration as universal: "there is no man who does not desire to revive the homeland in which he was born, and such a natural feeling cannot be condemned" (Ogiński 1827: 64). In the May 1811 memorandum to Alexander I, calling for the restoration of the Grand Duchy of Lithuania, Ogiński wrote:

In spite of natural revulsion which is felt upon exchanging independence for the duty to obey, in spite of various abuses in governing Lithuania, and, finally, in spite of the universal poverty outspread in this land, Lithuanians did not stop being loyal to the Russian monarch, since they came under his authority and are full of trust in the good will of Your Imperial Highness [...]. Therefore, [...] now is the good time to convince them that Your Highness looks after them and is ready to compensate for this loyalty by the means in Your power. [...] Today I will settle for a few words explaining what rights could be bestowed upon the Lithuanians and what impact this would have on the relations between citizens in the Duchy of Lithuania and Warsaw, and, finally, how this will benefit the Russian administration [...] (Ogiński 1827: 62-63).

The memorandum, addressed to Alexander I, clearly demonstrates Ogiński's efforts to retain the old civic identity, linked to the Grand Duchy of Lithuania as the country of his forefathers, rather than creating a new identity.

\section{In Place of Conclusions}

The analysis of the ego-documents of the Ogiński and the Plater families helps answer the question of why these two aristocrats, campaigning for the ideas of the Enlightenment, in 1795 chose different paths. Ogiński chose emigration in Italy where he developed close ties with the cultural elite of Florence, never 
abandoning the idea of active struggle, whereas Plater stayed in Lithuania. Plater entered compromises with the invaders, seeking to figure out the governing mechanism of the Russian Empire and to secure protection and support from the new government.

The answer to the question about the reasons behind these political choices is, in my opinion, related not only to the different political orientations of the two men, but also in their differing political aspirations. Ogiński was part of the proPrussian faction in Poland and Lithuania, supported by the nations of Western Europe. Whereas Plater, since the beginning of his career, was of the pro-Russian political persuasion.

Having estates in Livonia, Plater closely cooperated with the Russian imperial government from which he received certain protection. When the Russian army entered Lithuania in 1792, Plater's foremost concern was to avoid the stationing of the Russian military units in his manors. His pro-Russian stance determined his submissive attitude to the invaders and lack of resistance. As a cosmopolite, Plater saw himself as a citizen of a 'global' world, governed by the Russian officials. Therefore, it is not surprising that at the beginning of 1795, as the vice-chancellor of Lithuania, Plater personally handed over the collection of the Lithuanian Archive - the Lithuanian Metrica - into the hands of the Russian general Nikolai Repnin. Whereas Ogiński, even though he had been forced to enter a compromise with Russia in 1792 because of his sequestered manors, always remained faithful to the idea of the Grand Duchy of Lithuania and felt more affinity with Western Europe.

As regards cultural identity, Plater was satisfied with his 'micro world', which was limited to Lithuania, Courland, Livonia and, partially, Poland and Russia. For Ogiński such limits were too confining. Therefore, for Ogiński the process of reconciliation with the loss of the state and adjustment to the new situation in his homeland was long and complicated. The oath of allegiance, which he swore to the Emperor Alexander I in the early nineteenth century, as well as his senatorial office did not result in the emergence of a new identity. These steps were taken with a view to seeking the restoration of his country, the Grand Duchy of Lithuania.

Ogiński was a person of wide cultural interests, who was oriented towards Western Europe. His views were shaped and developed not as much in Warsaw, but in Berlin, The Hague, Amsterdam, London, and later Paris, Florence and Geneva. As a proponent of fundamental human and civil rights and freedoms, Ogiński was not able to implement them in Lithuania, which made him choose the life of exile in Italy. 


\section{BIBLIOGRAPHY}

\section{Primary sources}

\section{Archival sources}

\section{lietuvos valstybės istorijos archyvas [Lithuanian State Historical Archives, LVIA]}

Fond 1177, folder 1 (F1177/1)

"Conseil paternel à mon fils au moment de son entrée dans le monde". LVIA F1177/1, b. 87.

“Correspondence of the Ogiński family". LVIA, F1177/1, b. 104, 5803, 5827, 5832.

"Extrait d'une lettre adresée à ma femme, qui me consultait sur les livres polonais qu'on pourrait mettre entre les mains de nos enfans. Novembre 1822”. LVIA F1177/1, b. 5821.

"Lettre à ma fille Amélie, sur l'éducation des enfans. De Rétow en Samogitie, à Vilna. Au mois de Novembre 1822". LVIA, F1177/1, b. 5820.

Fond 1276 , folder 2 (F1276/2)

"Letters of Izabella Plater from Warsaw". January 1795. LVIA, F1276/2, b. 208, 1. 12-13, $15,39$.

"Letters of Izabella Plater to husband from Daugèliškis". September 1795. LVIA, F1276/2, b. 210, 1. 94-96.

"Letters of Izabella Plater to husband from Warsaw". 1787. LVIA, F1276/2, b. 179.

"Letters of Izabella Plater to husband from Warsaw". 1792. LVIA, F1276/2, b. 195, 1. 42-44, 48, 50 .

"Lithuanian nobility's letters addressed to Plater". LVIA, F1276/2, b. 192-212.

Lietuvos mokslų akademijos Vrublevskių bibliotekos Rankraščių skyrius [The Manuscript collection of the Wróblewski Library of the Lithuanian Academy of Science, LMAVB RS]

Fond 9 (F9)

Daugèliškis manor book catalogue. LMAVB RS, F9-63/II.

[Plater Kazimierz Konstanty]. 1792-1795. "Zapisy roczne Kazimierza Konstantego Platera 1792-1795”. LMAVB, RS F9-137.

[Plater Kazimierz Konstanty]. 1800-1803. "Dziennik Kazimierza Konstantego Platera z lat 1800-1803”. LMAVB RS, F9-68-71.

[Plater Kazimierz Konstanty]. 1803-1807. "Dziennik Kazimierza Konstantego Platera z lat 1805-1807”. LMAVB RS, F9-222.

Vilniaus universiteto bibliotekos Rankraščių skyrius [The Manuscript collection of the Vilnius University Library, VUB RS] 
Fond 1 (F1)

Diariusze sejmowe. Sejm grodzieński 1793 r. In: Elity polityczne Polski XVI-XVIII w. Ed. Jerzy Wisłocki, [online] http://www.bkpan.poznan.pl/projekty-zakonczone/ELITY/ SEJM1793/wstep.htm [10.04.2020].

[Ogiński Michel Kleofas]. 1778. "Mon manuscript commencé l'an 1778”. VUB RS, F1-C70, 1. 2-120.

[Ogiński Michel Kleofas]. 1786. "Uwagi obywatelskie nad stanem narodu naszego". VUB RS, F1-C95.

[Ogiński Michel Kleofas]. 1826. Ma Biographie depuis mon enfance jusquen 1788, époque où commencent mes Mémoires (manuscript). In: Mémoires de Michel Ogiński sur la Pologne et les Polonais, depuis 1788 jusqu'à la fin de 1815. Vol. I. Paris: chez Ponthieu. VUB RS, F1-D170, 1. 9-46.

[Ogiński Michał Kleofas]. 1793a. “Głos Jaśnie Wielmożnego Ogińskiego Podskarbiego Wielkiego Litewskiego na sesyi sejmowej in turno dnia 2 września 1793 roku miany”.

[Ogiński Michał Kleofas]. 1793b. “Głos Jaśnie Wielmożnego Ogińskiego Podskarbiego Wielkiego Litewskiego na sesyi sejmowej dnia 25 Septembra 1793 roku miany”.

[Ogiński Michał Kleofas]. 1793c. "Głos Jaśnie Wielmożnego Ogińskiego Podskarbiego W. W. X. Lit. dnia 9 Novembris 1793 roku miany”.

\section{Published sources}

[Oginski Michel]. 1826-1827. Mémoires de Michel Oginski sur la Pologne et les Polonais, depuis 1788 jusqu'à la fin de 1815. Vol. I-IV. Paris: chez L'Éditeur; chez Ponthieu; Genève: Barbezat et De Larue, Libraires.

[Oginski Michel]. 1827. Mémoires de Michel Oginski sur la Pologne et les Polonais, depuis 1788 jusqu'à la fin de 1815. Vol. III. Paris: Chez L'Éditeur Ponthieu, Libraire, Palais-Royal, Galerie De Bois; Geneve: Barbezat et De Larue, Libraires.

[Ogiński Michał Kleofas]. 1956. Listy o muzyce. Ed. Tadeusz Strumiłło. Kraków: Polskie Wydawnictwo Muzyczne.

Oginskis Mykolas Kleopas. 2014. Laiškai apie muzika. Vilnius: Regionų kultūrinių iniciatyvų centras. ISBN: 978-99-5581-816-8.

Oginskis Mykolas Kleopas. 2019. Priesakai sūnui ir kiti laiškai apie ugdymą. Ed. Vytas Rutkauskas, Ramunė Šmigelskytė-Stukienè. Klaipèda: DRUKA; [Rietavas]: Rietavo Ogińskių kultūros istorijos muziejus. ISBN: 978-60-9960-381-0.

[Plater Kazimierz Konstanty]. 1788a. Listy posta do ojca na wsi mieszkającego i odpowiedni w okolicznościach sejm teraźniejszych zatrudniających. Warszawa.

[Plater Kazimierz Konstanty]. 1788b (1789). Ziawienie o przysztym losie Polski. Warszawa: Drukarnia Uprzywileiowana J. K. Mci i Rzeczplitey Gröllowska. 
[Plater Kazimierz Konstanty]. 1789a. Mowy, zdania i przymówienia się. Warszawa: Piotr Zawadzki.

[Plater Kazimierz Konstanty]. 1789b. O banku narodowym w Polszcze ustanowić się tatwo mogacym. Warszawa: Drukarnia XX. Missyon.

[Plater Kazimierz Konstanty]. 1790. Kosmopolita do narodu polskiego. Warszawa: Drukarnia Wolna Jana Potockiego, [online] http://rcin.org.pl/ibl/dlibra/publication/18626/ edition/5107 [05.04.2020].

[Plater Kazimierz Konstanty]. 1791. Mowy, zdania y przymówienia się JW. Kazimierza Konstantego hr. Plater Kasztelana Trockiego na Seymie 1788 rozpoczętym a od czasu sesyów w nowym komplecie odbywaiących się miane. Warszawa: Drukarnia Piotra Zawadzkiego.

[Plater Kazimierz Konstanty]. 1856. Djarjusz podróż z Warszawy do Petersburga Hrab. Kazimierza Konst. de Bröhl Platera, starosty Inflanckiego póżniej Podkanclerza litewskiego w r. 1792 odbytej przepisany przez J.I. Kraszewskiego [1792]. "Czas", supplement to vol. 1 (4).

Tyszkiewicz Eustachy. 1870. Zrzódta do dziejów Kurlandyi i Semicalij z czasów Karola Królewicza Polskiego, Księcia Saskiego. Kraków: Księgarnia Władysława Jaworskiego.

\section{Secondary sources}

Bairašauskaitė Tamara. 2011. Tapatybè ir identifikacija XIX amžiaus istorijos tyrimuose: teorinis aspektas. "Lietuvos istorijos metraštis", no. 2. ISSN: 0202-3342. Pp. 51-68.

Beresnevičiūtè-Nosálová Halina. 2001. Lojalumų krizé: Lietuvos bajoru politinès sąmonès transformacija 1795-1831 metais. Vilnius: Vaga. ISBN: 54-1501-606-6.

Brusokas Eduardas. 2010. Mykolas Kleopas Oginskis 1794 m. sukilimo verpetuose. In: Kunigaikščiai Ogińskiai Lietuvos istorijoje. Kultūrinès veiklos pèdsakais. Ed. Ramunė Šmigelskytè-Stukienè. Vilnius: Vilniaus pedagoginio universiteto leidykla. ISBN: 978-99-5520-588-3. Pp. 153-168.

Castells Manuel. 2010. The Power of Identity. Oxford: Blackwell Publishing. ISBN: 978-14-0519-687-1.

Dundulis Bronius. 1972. Projektas atkurti Lietuvos Didžiają Kunigaikštystę Rusijos imperijos sudettyje (1811-1812). "Lietuvos TSR aukštųjų mokyklų mokslo darbai. Istorija”, no. 13 (1). ISSN: 0459-3456. Pp. 57-73.

Giddens Anthony. 1991. Modernity and Self-identity: Self and Society in the Late Modern Age. Stanford: Stanford University Press. ISBN: 0-8047-1943-8.

Grześkowiak-Krwawicz Anna. 2000. O formę rządu czy o rząd dusz? Publicystyka polityczna Sejmu Czteroletniego. Warszawa: Instytut Badań Literackich. ISBN: 978-83-87456-47-4.

Hall Stuart. 1990. Cultural Identity and Diaspora. In: Identity: Community, Culture, Difference. Ed. Jonathon Rutherford. London: Lawrence \& Wishart. ISBN: 978-08-5315-720-5. Pp. 222-237. 
Hall Stuart. 1994. Cultural Identity and Diaspora. In: Colonial Discourse and Postcolonial Theory. Ed. Patrick Williams, Laura Chrisman. New York: Columbia University Press. ISBN: 978-02-3110-021-2. Pp. 392-403.

Koç Mustafa. 2006. Cultural Identity Crisis in the Age of Globalization and Technology. "TOJET. The Turkish Online Journal of Educational Technology", vol. 5, no. 1. ISSN: 1303-6521. Pp. 37-43.

Konarski Szymon. 1967. Materiaty do biografi, genealogii i heraldyki polskiej. Vol. IV: Platerowie. Buenos Aires-Paryż.

Libiszowska Zofia. 1974. Misja Ogińskiego w Londynie. In: Wiek XVIII. Polska i Świat. Księga poświęcona Bogustawowi Leśnodorskiemu. Ed. Andrzej Zahorski. Warszawa: PIW. Pp. 177-193.

Mačiulytė Kristina. 2005. Kad Tèvynè gyvuotu.... XVIII amžiaus antrosios pusés Lietuvos Didžiosios Kunigaikštijos proginiai pamokslai. Vilnius: Lietuvių literatūros ir tautosakos institutas. ISBN: 99-5569-812-8.

Mačiulytė Kristina. 2006. Religinè ir pilietinè tapatybè LDKApšvietos pamoksluose. "Literatūra", no. 48 (7). ISSN: 0258-0802. Pp. 102-118.

Manteufflowa Maria. 1981. Plater (Broel-Plater) Ludwik August. In: Polski Stownik Biograficzny. Vol. XXVI. Wrocław: Zakład Narodowy im. Ossolińskich, Wydawnictwo PAN. ISBN: 83-0400-876-9. Pp. 679-683.

Rączka Teresa. 2013. Polsko-inflancka literatura romantyczna. Unpublished PhD thesis. Katowice: Uniwersytet Śląski.

Rolnik Dariusz. 2009a. Między Rzeczypospolita a Rosja, interesem wtasnym i postuga obywatelska. Wybory nie tylko polityczne Kazimierza Konstantego Platera (1749-1807). In: Pogranicza. Ludzie pogranicza. Ed. Waldemar Brenda, Jerzy Jarosław Kiełbik. Olsztyn: Towarzystwo Naukowe. Ośrodek Badań Naukowych im. Wojciecha Kętrzyńskiego. ISBN: 978-83-6083-931-7. Pp. 69-90.

Rolnik Dariusz. 2009b. Portret szlachty czasów stanistawowskich, epoki kryzysu, odrodzenia i upadku Rzeczypospolitej w pamiętnikach polskich. Katowice: Wydawnictwo Uniwersytetu Śląskiego. ISBN: 978-83-2261-796-0.

Sirutavičius Vladas. 1991. Konstituciniai sumanymai Lietuvoje XIX a. pradžioje (1816-1812 m.). In: Lietuvių Atgimimo istorijos studijos. Vol. 3: Lietuvos valstybès ideja (XIX a. - XX a. pradžia). Vilnius: Žaltvykslè. ISSN: 1392-0391. Pp. 7-28.

Šmigelskytè-Stukienė Ramunè. 2015a. Michat Kleofas Ogiński: Politician, Diplomat and Minister (1786-1794). Trans. Linas Andronovas. Vilnius: Petro ofsetas, and Rietavo Ogińskių kultūros istorijos muziejus. ISBN: 978-60-9420-479-1.

Šmigelskytè-Stukienè Ramunè. 2015b. Mykolas Kleopas Oginskis - Vilniaus miestietis. In: Kunigaikščiai Oginskiai Lietuvos istorijoje: kultūrinès veiklos pédsakais. [D.] 2: mokslo straipsniu rinkinys. Ed. Ramunẻ Šmigelskytė-Stukienè. Vilnius: Lietuvos istorijos instituto leidykla. ISBN: 978-60-9818-301-6. Pp. 104-132. 
Šmigelskytè-Stukienè Ramunè. 2018a. Tarp Ženevos, Florencijos ir Rietavo: Irenejjaus Kleopo Oginskio (1808-1863) kultürinés patirtys. In: Vakarykščio pasaulio atgarsiai. Mokslinin straipsniu rinkinys, skirtas Lietuvos valstybes atkürimo 100-osioms metinems. Ed. Margarita Matulytė, Romualdas Juzefovičius, Rimantas Balsys. Vilnius: Lietuvos dailės muziejus: Lietuvos kultūros tyrimų institutas. ISBN: 978-609-426-124-4. Pp. 156-167, 376.

Šmigelskytè-Stukienè Ramunè. 2018b. Veiklios moters kasdienybè: epizodas iš Izabelés Liudvikos Borch-Pliaterienés (1752-1813) gyvenimo. "XVIII amžiaus studijos", no. 4. ISSN: 2351-6968. Pp. 116-143.

Vilimas Darius. 2010. Oginskiai - Lietuvos Didžiosios Kunigaikštystès pavietu pareigünai XVI-XVII a. In: Kunigaikščiai Oginskiai Lietuvos istorijoje. Kultūrinès veiklos peedsakais. Ed. Ramunė Šmigelskytė-Stukienè. Vilnius: Vilniaus pedagoginio universiteto leidykla. ISBN: 978-9955-20-588-3. Pp. 17-28.

Zielińska Zofia. 1981a. Plater Kazimierz Konstanty. In: Polski Stownik Biograficzny. Vol. XXVI. Wrocław: Zakład Narodowy im Ossolińskich, Wydawnictwo PAN. ISBN: 83-0400-876-9. Pp. 665-672.

Zielińska Zofia. 1981b. Plater Konstanty Ludwik. In: Polski Stownik Biograficzny. Vol. XXVI. Wrocław: Zakład Narodowy im Ossolińskich, Wydawnictwo PAN. ISBN: 83-0400-876-9. Pp. 673-675.

Zielińska Zofia. 1991. „O sukcesyi tronu w Polszcze”. 1787-1790. Warszawa: PWN. ISBN: 83-1010-477-5.

Ramune Šmigelskyté-Stukienè

\title{
CIVIC AND CULTURAL IDENTITIES AND THE ENLIGHTENED LITHUANIAN NOBILITY (BASED ON THE EGO-DOCUMENTS OF THE OGIŃSKI AND PLATER FAMILIES)
}

\author{
(abstract)
}

The aim of this article is to examine the civic and cultural identities of two aristocrats who held important offices and belonged to the ruling elite of the Grand Duchy of Lithuania in the late eighteenth century: the last Vice-Chancellor of Lithuania, writer, and economist, Kazimierz Konstanty Plater (1749-1807), and the last Grand Treasurer of Lithuania, diplomat, and composer, Michal Kleofas Ogiński (1765-1833). The analysis of the egodocuments of the Ogiński and Plater families helps answer the question why these two aristocrats, promoting the ideas of the Enlightenment, in 1795 chose different paths: Ogiński emigrated to Italy where he developed close ties with the cultural elite of Florence 
but never abandoned the idea of active struggle, whereas Plater stayed in Lithuania. Plater made compromises with the invaders. He sought to figure out the governing mechanism of the Russian Empire and to secure protection and support from the new government.

Translated from Lithuanian by Linas Andronovas

\section{SŁOWA KLUCZOWE}

tożsamość obywatelska; tożsamość kulturowa; oświecenie; ród Platerów; ród Ogińskich; egodokumenty; korespondencja 